DOI: http://dx.doi.org/10.33846/ghs5307

\title{
Pengaruh Pijat Oksitosin Terhadap Produksi ASI (Air Susu Ibu) pada Ibu Post Partum di Wilayah Kerja Puskesmas Namlea Kabupaten Buru Tahun 2020
}

\author{
Dewi Susanti (koresponden) \\ (DIII Kebidanan, STIKes Maluku Husada) \\ Ratna Sari Rumakey \\ (IImu Keperawatan, STIKes Maluku Husada) \\ Iren Niak \\ (DIII Kebidanan, STIKes Maluku Husada)
}

\begin{abstract}
ABSTRAK
Refleks oksitosin dapat dipengaruhi oleh pikiran, perasaan dan emosi ibu. Perasaan ibu dapat meningkatkan dan juga menghambat pengeluaran oksitosin. Hormone ini akan menyebabkan sel-sel otot yang mengelilingi saluran pembuat susu mengerut atau berkontraksi sehingga ASI terdorong keluar dari saluran produksi ASI dan mengalir siap untuk dihisap oleh bayi. Sehingga kemungkinan jika ibu memiliki pikiran, perasaan dan emosi yang kuat, maka akan menekan refleks oksitosin dalam menghambat dan menurunkan produksi ASI. Penelitian ini menggunakan metode penelitian Praekperimental dengan rancangan penelitian One group pra-post test design. Populasi dalam penelitian ini adalah ibu post partum 52 orang menggunakan teknik ancidental sampling menggunakan uji statistik parametrik dengan uji non parametic Wilcoxon. Hasil penelitian ini menunjukan bahwa ada perbedaan sebelum dan setelah dilakukan tindakan pijat oksitosin dengan diperoleh nilai $p$-value sebesar 0,001 sehingga $p$-value $<\alpha(0,05)$ maka dapat disimpulkan bahwa ada perbedaan produksi ASI (air susu ibu) pre-test dan post-test dilakukan tindakan pijat oksitosin
\end{abstract}

Kata kunci: pijat oksitosin; produksi ASI (air susu ibu)

\section{PENDAHULUAN}

\section{Latar Belakang}

Air Susu lbu (ASI) merupakan sumber kehidupan bagi anak yang sangat penting dalam pertama kehidupan anak, dimana dalam air susu ibu terdapat banyak kandungan nutrisi yang dibutuhkan oleh anak yang menunjang tumbuh kembangnya seorang anak. ${ }^{(1)}$

Menyusui secara eksklusif selama 6 bulan terbukti memberikan resiko yang lebih kecil terhadap berbagai penyakit infeksi, seperti diare, infeksi saluran napas, infeksi telinga, pneumonia, dan infeksi saluran kemih. Selain itu pula dapat mengurangi resiko terhadap kejadian obesitas, alergi ataupun kanker.(1)

Cara yang dapat dilakukan untuk meningkatkan produksi ASI yang kurang dapat dilakukan tindakan nonfarmakologis pijat oksitosin yang dapat merangsang refleks oksitosin atau refleks letdown, selain itu dapat memberikan kenyamanan pada ibu, mengurangi bengkak, mengurangi sumbatan ASI, merangsang pelepasan hormone oksitosin, mempertahankan produksi ASI ketika ibu dan bayi sakit. ${ }^{(2)}$

Refleks oksitosin dapat dipengaruhi oleh pikiran, perasaan dan emosi ibu. Perasaan ibu dapat meningkatkan dan juga menghambat pengeluaran oksitosin. Hormone ini akan menyebabkan sel-sel otot yang mengelilingi saluran pembuat susu mengerut atau berkontraksi sehingga ASI terdorong keluar dari saluran produksi ASI dan mengalir siap untuk dihisap oleh bayi. Sehingga kemungkinan jika ibu memiliki pikiran, perasaan dan emosi yang kuat, maka akan menekan refleks oksitosin dalam menghambat dan menurunkan produksi ASI.(3)

Berdasarkan data dari Profil Kesehatan Indonesia Tahun 2018, cakupan persentase bayi yang mendapat ASI eksklusif di Indonesia yaitu sebesar 68,74\%. Pemerintah telah menargetkan pencapaian ASI eksklusif di Indonesia sebesar $80 \%$, namun hal itu belum tercapai sampai saat ini. Menurut Riset Kesehatan Dasar (Riskesdas) Tahun 2013 persentase tertinggi proses mulai menyusu pada anak umur 0-23 bulan adalah pada 1-6 jam $(35,2 \%)$. Proses mulai menyusu pada satu jam pertama setelah lahir atau IMD hanya $34,5 \% .^{(4)}$

Menurut data Profil Kesehatan Indonesia Tahun 2018 Maluku termasuk salah satu Provinsi dengan persentase terendah cakupan pemberian ASI eksklsuif dengan nilai persentase $(23,18 \%)$ tidak mencapai target Renstra tahun 2018 yaitu sebesar (47,0\%). ${ }^{(4)}$ 
Berdasarkan pengumpulan data awal di Ruang Bersalin Puskesmas Namlea Kabupaten Buru jumlah ibu post partum pada Tahun 2019 adalah 475, ibu post partu, pada tahun 2020 triwulan II 290 dan pada bulan September sampai Oktober Tahun 2020 adalah 52. Berdasarkan hasil observasi yang dilakukan pada tanggal 9-13 Juli 2020 data menunjukan bahwa pada 4 orang pasien mengalami kesulitan dalam menyusui karena ASI tidak keluar yang menyebabkan ibu mengalami bendungan ASI, dan bayi sering menangis. Berdasarkan hasil wawancara yang dilakukan oleh peneliti dengan salah satu bidan yang bertugas di Puskesmas Namlea bahwa bidan sudah memberikan informasi mengenai pemberian ASI eksklusif namun belum sering dilakukan intervensi atau tindakan pijat oksitosin yang diterapkan untuk merangsang produksi ASI pada ibu post partum di Puskesmas Namlea Kabupaten Buru.

Berdasarkan uraian diatas, Peneliti tertarik untuk meneliti tentang pengaruh pijat oksitosin terhadap produksi ASI pada ibu post partum Ibu di Ruang Puskesmas Namlea Kabupaten Buru.

\section{Hipotesis}

1. Pijat oksitosin tidak berpengaruh terhadap produksi ASI (Air Susu Ibu) pada ibu post partum di Wilayah Kerja Puskesmas Namlea Kabupaten Buru.

2. Pijat oksitosin berpengaruh terhadap produksi ASI (Air Susu lbu) pada ibu post partum di Wilayah Kerja Puskesmas Namlea Kabupaten Buru.

\section{METODE}

Penelitiann ini menggunakan metode penelitian Pra-ekperimental dengan rancangan penelitian One group pre-post test design ${ }^{(5)}$ Penelitian dilaksanakan di Wilayah Kerja Puskesmas Namlea Kabupaten Buru dan dilaksanakan selama 2 bulan. Populasi dalam penelitian ini berdasarkan data yang didapat di Puskesmas Namlea Kabupaten Buru dengan jumlah keseluruhan ibu post partum. ${ }^{(5)}$ pengambilan sampel menggunakan teknik ancidental sampling. ${ }^{(6)}$ Variable independen dalam penelitian ini yaitu pijat oksitosin, variable dependen dalam penelitian ini yaitu produksi ASI. Analisis data dalam penelitian ini yaitu analisis univariat dan analisis bivariat menggunakan uji paired sampel $t$-test dengan tingkat kemaknaan 0,5.

\section{HASIL}

Tabel 1. Karakteristik Responden

\begin{tabular}{|c|c|c|}
\hline Variabel & Frekuensi & Persentase \\
\hline Umur & 6 & \\
$19-25$ & 5 & 40,0 \\
$25-30$ & 3 & 33,3 \\
$30-35$ & 1 & 20,0 \\
$>40$ & 6 & 6,7 \\
\hline Paritas & 6 & 40,0 \\
Primipara & 3 & 40,0 \\
Multipara & & 20,0 \\
Grandemultipara & 6 & 40,0 \\
\hline Pekerjaan & 5 & 33,3 \\
PNS & 4 & 26,7 \\
Wiraswasta & & \\
IRT & 2 & 13,3 \\
Pendidikan & 6 & 40,0 \\
SMP & 2 & 33,3 \\
SMA & 5 & \\
DIII & & 26,7 \\
S1 & 4 & 73,3 \\
\hline YA & 11 & 100,0 \\
TIDAK & 15 & \\
\hline Perawatan Payudara & & \\
YA & & \\
TIDAK & & \\
\hline
\end{tabular}


Berdasarkan tabel 1 dapat disimpulkan bahwa jumlah responden sebanyak 15 ibu inpartu dengan mayoritas usia ibu kategori 19-25 tahun sebanyak 40,0\%. Karakteristik paritas dengan kategori primipara $40,0 \%$. Mayoritas pekerjaan PNS sebanyak 40,0\%, mayoritas pendidikan SMA $40,0 \%$. Mayoritas ibu post partum yang melakukan perawatan payudara hanya $26,7 \%$.

Tabel 2. Produksi ASI sebelum dan sesudah pijat oksitosin

\begin{tabular}{|l|c|c|}
\hline \multicolumn{1}{|c|}{ Produksi ASI } & Frekuensi & Persentase \\
\hline Pre Test & & \\
Cukup lancar 56-75 & 1 & 6,7 \\
Kurang lancar $<55 \%$ & 14 & 93,3 \\
\hline Post Tets & & \\
Lancar $76-100 \%$ & 15 & 100,00 \\
\hline
\end{tabular}

Tabel 2 menunjukan bahwa sebagian besar ibu post partum mengalami ASI kurang lancar pada pre-test sebanyak 14 orang, dan cukup lancar sebanyak 1 orang, Sedangkan produksi ASI pada post test pada keseluruhan ibu post partum mengalami produksi ASI lancar yaitu 15.

Tabel 3. Uji Normalitas

\begin{tabular}{|c|l|c|c|c|}
\hline \multicolumn{2}{|c|}{ Variabel } & \multicolumn{3}{|c|}{ Shapiro-Wilk } \\
\cline { 2 - 5 } & Statistik & df & Sig \\
\hline \multirow{3}{*}{ Produksi ASI } & Pre Test & 0,188 & 15 & 0,224 \\
\cline { 2 - 5 } & Post Test & 0,217 & 15 & 0,026 \\
\hline
\end{tabular}

Tabel 3 menunjukan bahwa Hasil uji normalitas menggunakan Shapiro Wilk diperoleh nilai $p$ value untuk nilai pre test 0,224 dan nilai $p$ value post tes 0,026 . Dengan nilai mean pre test 7,07 dan nilai mean post test 11,87 .

Tabel 4. Produksi ASI sebelum dan sesudah tindakan

\begin{tabular}{|l|c|c|c|}
\hline & Median & Minimum-Maksimum & Nilai $p$ \\
\hline Produksi ASI sebelum pijat oksitosin & 6,00 & $5-8$ & 0,001 \\
Produksi ASI sesudah Pijat Oksitosin & 12,00 & $10-13$ & \\
\hline
\end{tabular}

Berdasarkan Tabel 4 hasil uji non parametic Wilcoxon (p-value 0,001) karena nilai $p<0,05$, secara statistic terdapat perbedaan sebelum dan setelah dilakukan pijat oksitosin dengan diperoleh median 6 dengan nilai minimum-maksimum 5-8 produksi ASI sebelum dilakukan pijat oksitosin dan median 12 dengan nilai minimum-maksimum 10-13 sesudah dilakukan pijat oksitosin.

\section{PEMBAHASAN}

Karakteristik responden dalam penelitian ini yaitu 15 ibu post partum yang mengalami kesulitan menyusui dikarenakan ASI (air susu ibu) tidak keluar sehingga anak menjadi rewel. Berdasarkan hasil tersebut dapat disimpulkan bahwa terjadi peningkatan produksi ASI (air susu ibu) yang signifikan pada ibu post partum yang sudah dilakukan tindakan pijat oksitosin. ASI tidak keluar adalah kondisi tidak diproduksinya ASI atau sedikitnya produksi ASI. Hal ini disebabkan pengaruh hormone oksitosin yang kurang bekerja sebab kurangnya rangsangan isapan bayi yang mengaktifkan kerja hormone oksitosin. ${ }^{(7)}$

Pijat oksitosin merupakan salah satu solusi untuk mengatasi ketidak cukupnya ASI (air susu ibu). Pijat oksitosin adalah pemijatan pada sepanjang tulang belakang (vetebrae) sampai tulang castae kelima-keenam dan merupakan usaha untuk merangang hormon prolaktin dan oksitosin setelah melahirkan. Pijatan ini berfungsi untuk meningkatkan hormon oksitosin yang dapat menenangkan ibu, sehingga ASI (air susu ibu) pun keluar. ${ }^{(7)}$

Hasil penelitian ini sejalan dengan penelitian yang dilakukan oleh peneliti sebelumnya di Klinik Pratama Nining Pelawati, didapatkan bahwa peningkatan produksi ASI ini disebabkan karena peningkatan rasa nyaman dan rileks pada saat diberikan pijat oksitosin yang secara otomatis akan merangsang keluarnya hormon oksitosin (refleks let down) dari kelenjar-kelenjar pituitari dimana hormon oksitosin akan merangsang pengeluaran ASI (air susu ibu) pada ibu post partum sehingga 
produksi ASI (air susu ibu). Selain itu pijat oksitosin juga memiliki manfaat yang lain seperti menenangkan dan mengurangi stres, membangkitkan rasa percaya diri, membantu ibu post partum agar mempunyai pikiran dan perasaan yang baik tentang bayinya, dan sebagainya. ${ }^{(8)}$

Pijat oksitosin berpengaruh terhadap produksi ASI (air susu ibu) pada ibu post partum. Hal ini karena dengan melakukan pijat oksitosin serta dapat melancarkan sirkulasi darah sehingga dapat mencegah penyumbatan saluran ASI (air susu ibu). Dengan melakukan pijat oksitosin secara rutin pada ibu post partum makan akan melancarkan produksi ASI (air susu ibu) pada ibu. ${ }^{(3)}$

Salah satu tindakan yang perlu dilakukan untuk memaksimalkan kualitas dan kuantitas ASI (air susu ibu), yaitu pemijatan punggung. Pemijatan punggung ini berguna untuk merangsang pengeluaran hormon oksitosin menjadi lebih optimal dan pengeluaran ASI (air susu ibu) menjadi lancar. ${ }^{(14)}$

\section{KESIMPULAN}

Ada perbedaan yang signifikan antara sebelum dan sesudah dilakukan tindakan pijat oksitosin terhadap produksi ASI (air susu ibu) pada ibu post partum di Wilayah Kerja Puskesmas Namlea Kabupaten Buru dengan. Ada pengaruh pijat oksitosin terhadap produksi ASI (air susu ibu) pada ibu post partum di Wilayah Kerja Puskesmas Namlea Kabupaten Buru.

\section{DAFTAR PUSTAKA}

1. Jauhari, I., Fitriani, R., \& Bustami. (2018). Perlindungan Hak Anak Terhadap Pemberian Air Susu Ibu (ASI). Yogyakarta: Deepublish.

2. Wulandari, N. F. (2020). Happy Exclusive Breastfeeding. (D. Nhadiva, Ed.) Yogyakarta: Laksana.

3. Italia, \& Yanti, M. S. (2018). Pengaruh Pijat Oksitosin Terhadap Produksi ASI Pada lbu Post Partum di BPM MELI R. PALEMBANG Tahun 2018. Jurnal Kesehatan dan Pengembangan, 3846.

4. Primadi, O. (2018). Health Statistikcs. Jakarta: Kementerian Kesehatan Republik Indonesia.

5. Nursalam. (2015). Metodologi Penelitian Ilmu Keperawatan: Pendekatan Praktis (Vol. 4). (P. P. Lestari, Ed.) Jakarta: Salemba Medika. Retrieved from https://www.penerbitsalemba.com

6. Swarjana, I. (2012). Metodologi Penelitian Kesehatan; Tuntutan Praktis Pembuatan Proposal Penelitian. Yogyakarta: CV ANDI OFFSET.

7. Asih, Y. (2017). Pengaruh Pijat Oksitosin Terhadap Produksi ASI. Jurnal Keperawatan, 209-214.

8. Saputri, I. N., Ginting, D. Y., \& Zendato, I. C. (2019). Pengaruh Pijat Oksitosin Terhadap Produksi ASI Pada Ibu Post Partum. Jurnal Kebidanan Kestra (JKK), 68-73.

9. Hanum, S. M., Purwanti, Y., \& Khumairoh, I. R. (2015). Efektifitas Pijat Oksitosin Terhadap Produksi ASI. Midwiferia, 1-6. 